\title{
REFERENCE EVAPOTRANSPIRATION BASED ON CLASS A PAN EVAPORATION
}

\author{
Marco Antônio Fonseca Conceição \\ Embrapa Uva e Vinho - Estação Experimental de Jales , C.P. 241 - CEP: 15700-000 - Jales, SP. \\ e-mail <mafconce@uol.com.br>
}

\begin{abstract}
Estimating reference evapotranspiration (ETo) based on Class A pan evaporation (ECA) is very usual in irrigated areas. For this purpose the ECA values are multiplied by a pan coefficient (Kp) to obtain ETo. $\mathrm{Kp}$ values can be estimated in different ways being, however, important to know which method would estimate the best value for a given locality. In the present work estimated values of ETo based on Class A pan evaporation, using $\mathrm{Kp}$ values determined by different methods, were compared to Penman-Monteith-FAO (EToPM) values for the northwest region of the São Paulo State, Brazil. The annual average $\mathrm{Kp}$, determined dividing EToPM by ECA, was 0.74 . For the rainy months (December to March) the average Kp value was 0.80 and for the dry months (April to November) 0.70 . The reference evapotranspiration estimated using Kp determined by the Snyder equation presented the best regression coefficients when compared to EToPM.
\end{abstract}

Key words: Penman-Monteith, pan coefficient, irrigation

\section{EVAPOTRANSPIRAÇÃO DE REFERÊNCIA COM BASE NA EVAPORAÇÃO DO TANQUE CLASSE A}

\begin{abstract}
RESUMO: A estimativa da evapotranspiração de referência (ETo) com base na evaporação do tanque Classe $A(E C A)$ é bastante comum em áreas irrigadas. Para isso multiplica-se o valor de ECA por um coeficiente do tanque (Kp) determinando-se, assim, o valor de ETo. O valor de Kp pode ser determinado de diferentes formas, necessitando-se, contudo, averiguar-se qual a metodologia que propicia a melhor estimativa de ETo a partir de valores de ECA, no local desejado. No presente trabalho foram estimados os valores da evapotranspiração de referência (ETo) para as condições da região noroeste do Estado de São Paulo, a partir de dados do tanque Classe A (ECA), utilizando-se diferentes métodos de determinação do coeficiente do tanque (Kp). Esses valores de ETo foram comparados com os obtidos empregando-se 0 modelo de Penman-Monteith conforme a parametrização da FAO (EToPM). O valor médio anual de Kp, determinado a partir da relação entre EToPM e ECA, foi de 0,74. No período chuvoso (dezembro a março) o Kp médio foi de, aproximadamente, 0,80 e no período seco (abril a novembro) foi de 0,70. A estimativa da ETo através do tanque Classe A, empregando-se o modelo de Snyder para determinação de $\mathrm{Kp}$, foi a que proporcionou os maiores coeficientes de determinação e de confiança em relação a EToPM.

Palavras-chave: Penman-Monteith, coeficiente do tanque, irrigação
\end{abstract}

\section{INTRODUCTION}

Irrigated fruticulture area has increased in an accentuated way in the northwest region of the São Paulo state, Brazil. For an efficient water management it is necessary to know the water requirement of irrigated crops during their respective yield cycles. Estimating this requirement is based, normally, on local reference evapotranspiration (ETo) data, multiplied by specific crop coefficients $(\mathrm{Kc})$ for each development stage (Doorenbos \& Pruitt, 1997).

Currently the Penman-Monteith-FAO is the most usual model to determine ETo (Sediyama, 1996). Agrometeorological stations, however, are not always sufficiently equipped to collect the necessary data to run this model (Chiew et al., 1995). For this reason, other methods are normally employed to determine ETo, the class A pan being one of the most used in irrigation projects (Pereira et al., 1997).
To convert class $A$ pan evaporation (ECA) into ETo a coefficient $(\mathrm{Kp})$ is used, which depends on the fetch distance around the pan (F), wind speed (Ws) and air relative humidity $(\mathrm{RH})$. To determine $\mathrm{Kp}$ charted values or equations can be employed, where $\mathrm{Kp}$ is a function of F, Ws and RH (Doorenbos \& Pruit, 1997).

Therefore, what should be known is which method of $\mathrm{Kp}$ determination is the best one to estimate ETo. Otherwise, in many irrigated areas, class A pans are installed without the necessary instrumentation to measure $\mathrm{Ws}$ and $\mathrm{RH}$, becoming usual, in these cases, to use constant $\mathrm{Kp}$ values for ETo calculation.

This work had the objective of estimating ETo values from class $A$ pan evaporation data using different methods to determine $\mathrm{Kp}$, and to compare these values with those obtained by the Penman-Monteith-FAO model in the conditions of the northwest region of the São Paulo state. 


\section{MATERIAL AND METHODS}

Ten year meteorological data from the São Paulo Electricity Company (CESP) Água Vermelha Hidrometeorological Station, located at $19^{\circ} 53^{\prime} \mathrm{S}, 50^{\circ} 19^{\prime}$ $\mathrm{W}$, and $445 \mathrm{~m}$ above sea level were utilized. Available climatic elements used were: monthly average values of maximum air temperature (Tmax), mean air temperature $(\mathrm{T})$, minimum air temperature (Tmin), air relative humidity $(\mathrm{RH})$, total sunshine hours $(\mathrm{n})$, wind speed at $2.0 \mathrm{~m}$ height (Ws) and class A pan evaporation (ECA).

Reference evapotranspiration (ETo) was calculated after Pereira et al. (1997), using the PenmanMonteith-FAO model. The incident solar radiation was estimated by the Glover \& McCulloch (1958) relation, as presented by Pereira et al. (1997).

$\mathrm{Kp}$ monthly values were determined based on $\mathrm{RH}$, Ws and fetch distance $(\mathrm{F})$ using the FAO chart (Doorenbos \& Pruit, 1997), Snyder (1992) and Pereira et al. (1995) equations. These equations can be written as follows:

$\mathrm{Kp}=0.482+0.024 \operatorname{Ln}(\mathrm{F})-0.000376{ }^{*} \mathrm{Ws}+0.0045{ }^{*} \mathrm{RH}$

(Snyder, 1992)

$\mathrm{Kp}=0.85^{*}(\mathrm{~s}+\gamma) /\left[\mathrm{s}+\gamma^{*}\left(1+0.33^{*} \mathrm{Ws}\right)\right] \quad$ (Pereira et al., 1995)

where (s) is the slope of the saturated vapor pressure versus temperature curve $\left(\mathrm{kPa}{ }^{\circ} \mathrm{C}^{-1}\right)$; and $(\gamma)$ the psicometric coefficient $\left(\mathrm{kPa}{ }^{\circ} \mathrm{C}^{-1}\right)$.

$\mathrm{Kp}$ values were obtained considering: a) the annual period; $b$ ) the rainy period (December to March); c) the dry period (April to November) when, normally, producers use irrigation more frequently. From the angular coefficients obtained by regression between EToPM and ECA approximate Kp values were fixed for the dry and rainy periods, and multiplied by ECA, yielding the adjusted ETo values (EToCAa).

FAO charted $\mathrm{Kp}$ values and those obtained from Snyder (1992) and Pereira et al. (1995) equations were also multiplied by ECA to obtain reference evapotranspiration estimations EToCAf, EToCAs and
EToCAp, respectively. These ETo estimated values were compared to EToPM data using linear regression, giving respective determination coefficients $\left(R^{2}\right)$. A confidence coefficient (c) was also utilized, as proposed by Camargo \& Sentelhas (1997), that corresponds to the product of the correlation coefficient $(r)$ by the exactness coefficient (d) (Wilmott et al., 1985, mentioned by Camargo \& Sentelhas, 1997). The value of (d) was calculated through the following expression:

$$
\mathrm{d}=1-\left[\Sigma(\mathrm{Pi}-\mathrm{Oi})^{2} / \Sigma(|\mathrm{Pi}-\mathrm{O}|+|\mathrm{Oi}-\mathrm{O}|)^{2}\right]
$$

where $(\mathrm{Pi})$ are values estimated from $\mathrm{ECA}$; $(\mathrm{Oi})$ are obtained values utilizing the Penman-Monteith-FAO model (EToPM); and $(O)$ is the average of EToPM values.

To evaluate data performance in relation to the confidence coefficient (c), Camargo \& Sentelhas (1997) presented a scale varying from values smaller or equal to 0.40 (very bad performance) to values greater than 0.85 (excellent performance).

\section{RESULTS AND DISCUSSION}

ECA values were correlated to ETo data determined by the Penman-Monteith-FAO method (EToPM) yielding linear models passing through the origin, with the angular coefficients becoming equal to the average $\mathrm{Kp}$ values for the periods under study (Figure 1). Annual $\mathrm{Kp}$ was 0.7411 , being closer to the Terra et al. (1998) suggested value of 0.75 than to that of Telles (1996) 0.70, obtained for the São Paulo northwest region.

For the December-March period the average Kp was 0.8119 (Figure 1), showing that ECA becomes closer to EToPM in the rainy period as compared to the dry one, because of a smaller advection effect over water evaporation (Pereira et al., 1997).

For the April-November dry period, when there is a greater demand for irrigation, the average $\mathrm{Kp}$ value was 0.7048 . This value is in agreement with FAO chart data, which present smaller Kp values for low air relative humidity and high wind speed conditions (Doorenbos \& Pruitt, 1997).
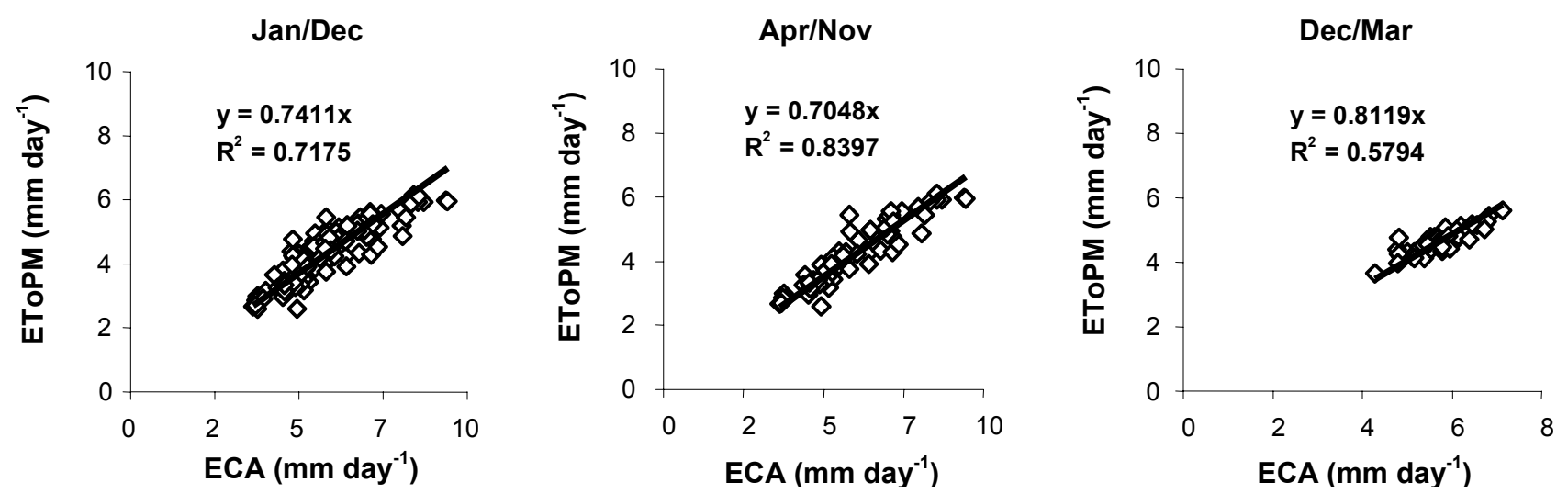

Figure 1 - Relations between class A pan evaporation (ECA) and Penman-Monteith-FAO reference evapotranspiration (EToPM). 
The April-November period class A pan evaporation values presented greater amplitude in relation to the rainy period, showing that the evaporative demand of December to March has a smaller variability than that of the dry period (Figure 1).

From the angular regression coefficients (Figure 1) the mean 0.80 and $0.70 \mathrm{Kp}$ values were fixed for the rainy and dry periods, respectively, that were used for the adjusted reference evapotranspiration (EToCAa) estimation, multiplying them by class $\mathrm{A}$ pan evaporation data.

The graphs of Figure 2 compare EToCAa, EToCAs, EToCAp and EToCAf with EToPM values. The determination coefficient $R^{2}$ was greater $(0.8704)$ when $\mathrm{Kp}$ values were calculated by the Snyder (1992) equation. EToCAs also provided the best confidence coefficient (c) value, equal to 0.883 (Table 1), that can be classified as excellent according to the Camargo \& Sentelhas (1997) criterion.

In sequence, EToCAa values were adjusted, resulting a $R^{2}$ equal to 0.8148 and (c) equal to 0.876 , that

Table 1 - Determination coefficient $\left(R^{2}\right)$ and confidence coefficient (c)" values.

\begin{tabular}{lcccc}
\hline Coefficient & EToCAa & EToCAs & EToCAp & EToCAF \\
\hline $\mathrm{R}^{2}$ & 0.814 & 0.870 & 0.811 & 0.787 \\
$\mathrm{C}$ & 0.876 & 0.883 & 0.854 & 0.739 \\
\hline
\end{tabular}
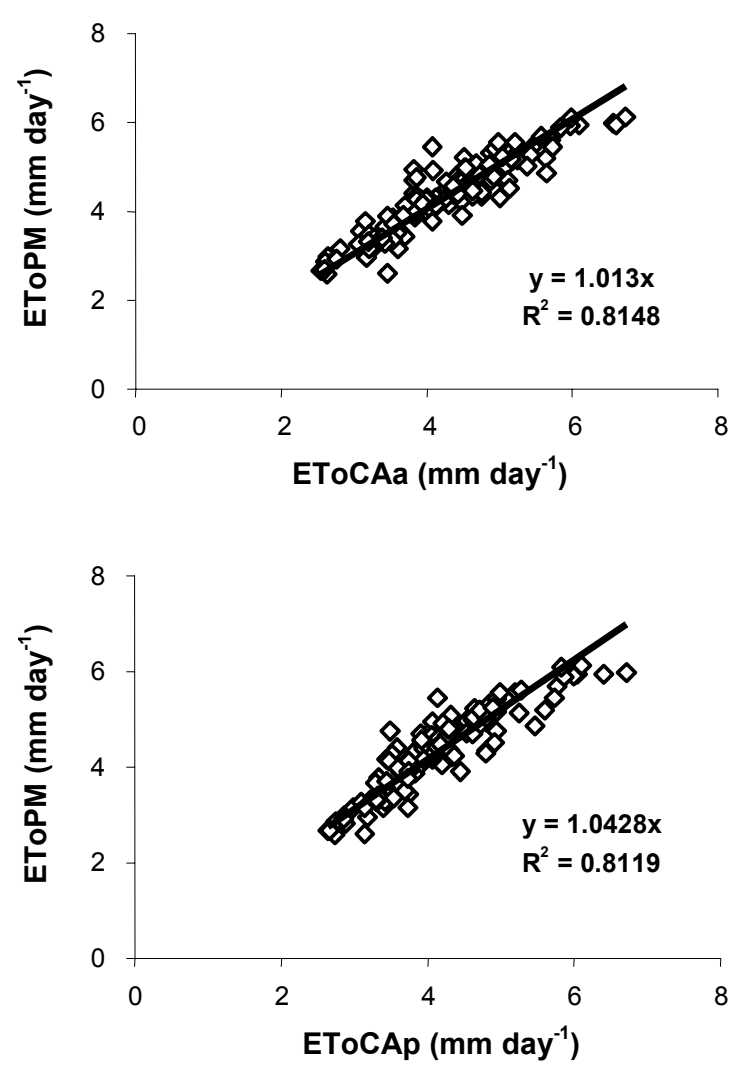

can, also, be considered as an excellent. Values obtained by the Pereira et al. (1995) equation gave a $R^{2}$ value equal to 0.8119 and (c) equal to 0.854 , remaining near to the lower limit of excellent performance $(0.85)$.

Reference evapotranspiration values estimated using charted FAO Kp coefficients presented the worst performance, with $R^{2}$ equal to 0.7878 (Figure 2) and (c) equal to 0.739 (Table 1), which can be classified as a good performance according to the rule of Camargo \& Sentelhas (1997).

The best performance of Snyder (1992) and Pereira et al. (1995) equations shows that the use of continuous values provided by equations is more suitable than the use of discreet values provided by charts and tables. The last ones are maintained constant for relatively wide $\mathrm{RH}$ or Ws bands.

For $1.0 \mathrm{~m}$ fetch distance and a same wind condition, smaller than $175 \mathrm{~km}$ day $^{-1}$, for example, the Kp value will be 0.65 for $\mathrm{RH}$ equal $41 \%$ or $69 \%$. If $\mathrm{RH}$ increases to $71 \%$, the $\mathrm{Kp}$ value will also present an expressive increase, assuming a new value equal to 0.75 . These variations can be smoothed using equations, resulting estimated ETo values in accordance to values obtained by the Penman-Monteith-FAO model.

The Pereira et al. (1995) equation does not include the fetch $(F)$ distance, which, according to the authors, can present great variations between dry and rainy conditions. Since the analysis was done at a
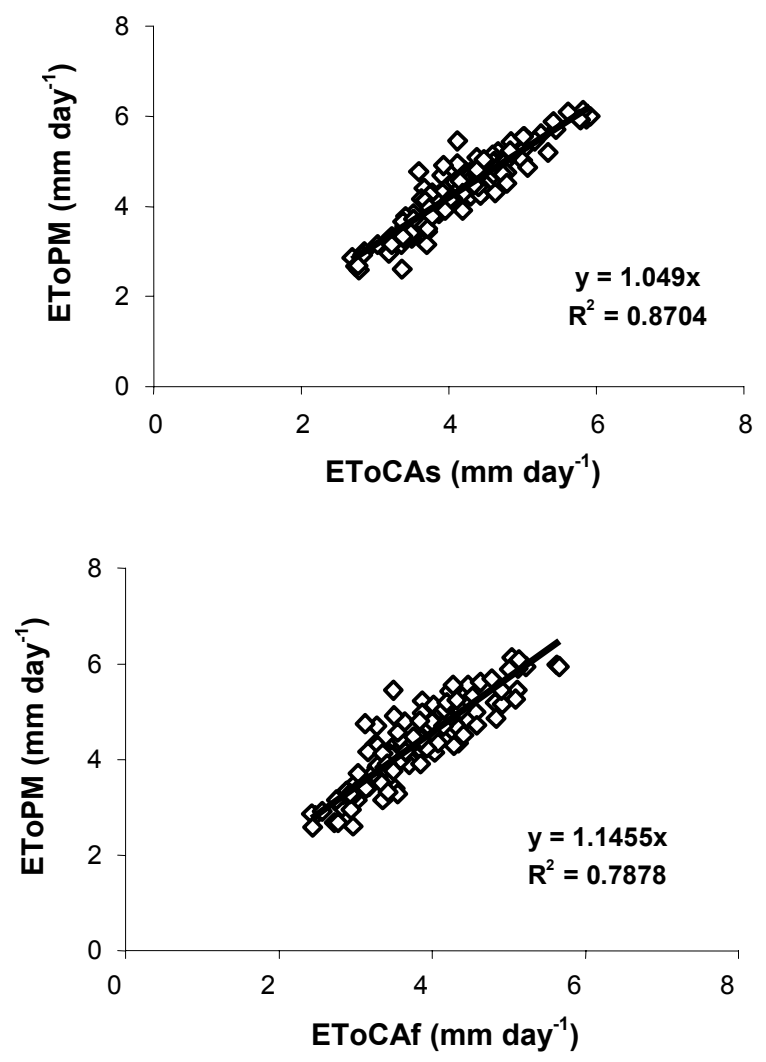

Figure 2 - Relations among Penman-Momteith-FAO reference evapotranspiration values (EToPM) and estimated ETo values using adjusted coefficients (EToCAa), Snyder equation (EToCAs), Pereira et al. equation (EToCAp); and charted FAO values (EToCAf). 
monthly scale, these variations were probably not so significant to restrict the use of a constant fetch distance value, as in the case of the Snyder (1992) equation. If a daily analysis would have been made, it could be possible that the use of a constant fetch distance could reduce the Snyder (1992) equation to a relative performance, as compared to the Pereira et al. (1995) equation, at least for the rainy period, when a reduction of the effective fetch distance occurs after a rainfall, as a consequence of changes in weather and soil conditions.

The use of $\mathrm{Kp}$ fixed values to estimate the reference evapotranspiration (EToCAa) was a very satisfactory way for a monthly scale. In a period of same weather conditions, when UR and $V v$ do not present great variations, using a fixed $\mathrm{Kp}$ value provided better ETo estimations than using charted values.

In relation to the former example, if $\mathrm{RH}$ changes from $71 \%$ to $69 \%$, the charted $\mathrm{Kp}$ values will vary from 0.75 to 0.65 , representing a decrease of almost $9 \%$ of the estimated EToCA (considering the same ECA). These variations are avoided using $\mathrm{Kp}$ fixed values. $\mathrm{Kp}$ fixed value performance was higher than those of Pereira et al. (1995), staying close to the Snyder (1992) equation performance. Thus, in the region under study, the use of the Snyder (1992) equation to calculate ETo based on class A pan evaporation (ECA) can be recommended for areas with available $\mathrm{RH}$ and Ws records. Otherwise, in areas with only ECA records, fixed $\mathrm{Kp}$ values equal to 0.80 and 0.70 , for December-March and April-November periods, respectively, should be used.

\section{CONCLUSION}

Class A pan coefficients $(\mathrm{Kp})$ calculated by the Snyder (1992) equation provided the best reference evapotranspiration (ETo) estimation, for the São Paulo northwest region conditions.

\section{REFERENCES}

CAMARGO, A.P. de; SENTELHAS, P.C. Avaliação do desempenho de diferentes métodos de estimativa da evapotranspiração potencial no Estado de São Paulo, Brasil. Revista Brasileira de Agrometeorologia, v.5, p.89-97, 1997.

CHIEW, F.H.S.; KAMALADASA, N.N.; MALANO, H.M.; McMAHON, T.A. Penman-Monteith, FAO-24 reference crop evapotranspiration and class-A pan data in Australia. Agricultural Water Management, v.28, p.9-21, 1995.

DOORENBOS, J.; PRUITT, W.O. Necessidade hídrica das culturas. Campina Grande: UFPB, 1997. 204p. (Estudos FAO: Irrigação e Drenagem, 24).

PEREIRA, A.R.; VILLA NOVA, N.; PEREIRA, A.S.; BARBIERI, V. A model for the class A pan coefficient. Agricultural Water Management, v.76, p.75-82, 1995.

PEREIRA, A.R.; VILLA NOVA, N.A.; SEDIYAMA, G.C. Evapo(transpi)ração. Piracicaba: FEALQ, 1997. 183p.

SEDIYAMA, G.C. Estimativa da evapotranspiração: histórico, evolução e análise crítica. Revista Brasileira de Agrometeorologia, v.4, p.1-12, 1996.

SNYDER, R.L. Equation for evaporation pan to evapotranspiration conversions. Journal of Irrigation and Drainage Engineering, v.118, p.977-980, 1992.

TELLES, D. de A. Evapotranspiração de referência e demandas potenciais na região de Jales - SP. In: CONGRESSO NACIONAL DE IRRIGAÇÃO E DRENAGEM, 11., Campinas, 1996. Anais. Campinas: ABID, 1996. p.147162.

TERRA, M.M.; PIRES, E.J.P.; NOGUEIRA, N.A.M. Tecnologia para produção de uva Itália na região noroeste do Estado de São Paulo. Campinas: CATI, 1998. 81p. (Documento Técnico, 97).

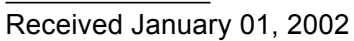

